DOI: https://doi.org/10.47405/mjssh.v6i9.980

\begin{tabular}{|c|c|}
\hline & Malaysian Journal of Social Sciences and Humanities (MJSSH) \\
\hline Malaysian Journal of & Volume 6, Issue 9, September 2021 \\
\hline (MJ-SSH) & e-ISSN : 2504-8562 \\
\hline & $\begin{array}{l}\text { Journal home page: } \\
\text { www.msocialsciences.com }\end{array}$ \\
\hline
\end{tabular}

\title{
Personaliti Grit dan Kesejahteraan Subjektif Pelajar Universiti
}

\author{
Muhammad Syaril Anwar Mustaza' ${ }^{1}$, Faridah Mydin Kutty ${ }^{1}$ \\ ${ }^{1}$ Fakulti Pendidikan, Universiti Kebangsaan Malaysia (UKM)
}

Correspondence: Muhammad Syaril Anwar Mustaza (p103937@siswa.ukm.edu.my)

\begin{abstract}
Abstrak
Sikap tabah, ketekunan serta bersedia berhadapan dengan perubahan di luar jangka adalah nilai penting yang perlu wujud dalam diri seseorang mahasiswa. personaliti grit dan kesejahteraan subjektif mempengaruhi kualiti pembelajaran pelajar. Reka bentuk kajian kuantitatif berbentuk tinjauan dipilih bagi mengenal pasti tahap personaliti grit dan kesejahteraan subjektif pelajar dan hubungan antara kedua-dua pemboleh ubah tersebut turut di lihat. Sejumlah 387 orang responden dalam kalangan pelajar UKM dipilih dengan menggunakan teknik persampelan rawak berkelompok. Instrumen kajian Short Grit Scale (Grit-S) dan College Student Subjective Wellbeing Questionnaire yang diadaptasi digunakan bagi tujuan pengumpulan data.. Hasil analisis menunjukkan pelajar mempunyai tahap grit yang sederhana tinggi (s.p. $=0.866)$ dan mempunyai tahap kesejahteraan subjektif yang tinggi (s.p. $=$ 1.064). Manakala, hubungan korelasi menunjukkan terdapat hubungan yang positif dan signifikan antara personaliti grit terhadap kesejahteraan subjektif $(\mathrm{r}=0.357, \mathrm{p}<0.01)$. Model analisis regresi linear menunjukkan grit secara kolektif menyumbang $12.5 \%$ terhadap konstruk kesejahteraan subjektif pelajar. Kajian ini memberikan gambaran bahawa tahap kesejahteraan subjektif pelajar akan meningkat sekiranya tahap personaliti grit meningkat. Personaliti grit dan Kesejahteraan subjektif pelajar adalah penting kerana ia memberikan gambaran terhadap kemampuan pelajar menghadapi pembelajaran sepanjang musim pandemik yang sangat mencabar. Selain itu juga, aspek personaliti grit mampu di jadikan sebagai petunjuk kepada kesejahteraan subjektif pelajar. Dapatan ini juga menambahkan lagi maklumat dan pengetahuan berkenaan topik personaliti grit yang masih kurang dikaji secara menyeluruh.
\end{abstract}

Kata kunci: personaliti grit, kesejahteraan subjektif pelajar, pandemik Covid-19, Malaysia

\section{Grit Personality and Subjective Wellbeing of University Students}

\begin{abstract}
Perseverance, diligence and willingness to deal with contingent changes are important values that needs to exist within a student. Grit personality and subjective well-being affect the quality of student learning. The quantitative research design is used to identify the level of grit personality and the subjective well-being of the students and the relationship between the two variables is also seen. A total of 387 respondents among UKM students were selected using random sampling techniques. Short Grit Scale (Grit-S) and College Student Subjective Wellbeing Questionnaire were adapated and used for data collection. The results of analysis show that students have a moderate high level of grit (s.d. = 0.866) and have a high level of subjective well-being (s.d. = 1.064). Meanwhile, correlation relationships show that there is a positive and significant relationship between the grit personality against students subjective wellbeing $(r=0.357, \mathrm{p}<0.01)$. $)$. Multiple regression analysis models show
\end{abstract}


grit collectively account for $12.5 \%$ of student subjective well-being construct. In other words, student subjective well-being will increase when personality grit increases. Grit personality and student subjective well-being are important as it provides an overview of the ability of students to face learning throughout the pandemic season. In addition, the aspect of Grit personality is capable to predict subjective well-being of students. This finding also increases information and knowledge on the topic of Grit personality that is still under review.

Keywords: grit personality, resilience, student subjective well-being, pandemic Covid-19, Malaysia

\section{Pengenalan}

Pandemik covid-19 membawa dimensi baharu dalam sistem pembelajaran di pelbagai peringkat institusi pendidikan. Bagi pelajar di institusi pengajian tinggi sistem pembelajaran beralih kepada pembelajaran secara dalam talian (online learning). Memandangkan landskap pengajaran dan pemudahcaraan telah berubah, pelajar perlu beradaptasi dengan norma baharu bagi melangsungkan proses pembelajaran. Dalam hal ini, kebolehan untuk beradaptasi terhadap cabaran pembelajaran norma baharu amat penting kerana kegagalan untuk beradaptasi meningkatkan risiko terhadap kesihatan mental, kesihatan fizikal dan kesejahteraan umum (Zacher \& Rudolph 2021). Tambahan pula, dalam konteks pelajar universiti, kesejahteraan subjektif turut dilihat sebagai salah satu faktor yang penting dalam mengikuti pembelajaran di musim wabak pandemik Covid-19 (O'Connor et al., 2020; Rigotti et al., 2020).

Oleh itu, terdapat keperluan untuk mengkaji tahap kesejahteraan subjektif pelajar memandangkan ia adalah faktor penyumbang kepada kebahagiaan seseorang individu (Ariati, 2010). Tambahan pula, kesejahteraan subjektif merupakan petunjuk penting bagi menentukan tahap kepuasan hidup, tahap kesihatan mental dan fizikal dalam memastikan produktiviti pelajar dalam pembelajaran (Ed Diener, 1984; Renshaw, 2018). Moen dan Olsen (2020) telah membuktikan bahawa terdapat hubungan yang signifikan antara aspek kesejahteraan subjektif terhadap pencapaian akademik, kesejahteraan emosi, kepuasan hidup serta hubungan sosial yang sihat. Berdasarkan dapatan ini, dirumuskan bahawa aspek kesejahteraan subjektif pelajar perlu diberikan perhatian oleh universiti..

Terdapat pelbagai faktor yang mempengaruhi kesejahteraan subjektif antaranya adalah faktor kesyukuran, keperibadian, optimisme, harga diri, budaya setempat, pengaruh dalam masyarakat, sokongan sosial serta faktor demografi (E. Diener et al., 1999; Ed Diener et al., 2003). Kajian berkenaan kesejahteraan subjektif dikembangkan lagi menerusi pendekatan yang lain seperti hubungannya dengan faktor personaliti. Antaranya, personaliti grit memandangkan ia personaliti yang masih baru dalam bidang psikologi positif (Lam \& Zhou, 2019)

Grit merupakan salah satu tret personaliti yang menjelaskan kemampuan seseorang untuk mengekalkan keazaman dan motivasi dalam jangka masa yang panjang walaupun sedang mengharungi kegagalan atau kesusahan (Duckworth et al., 2007). Konsep grit yang diperkenalkan Duckworth et al. (2007) yang menerangkan berkenaan keberanian, kecekalan, kesungguhan, dan daya tahan seseorang dalam mengharungi kesusahan. Berdasarkan Lam dan Zhou (2019), topik personaliti grit digunakan secara meluas untuk melihat hubungan grit terhadap kesihatan mental, motivasi belajar, dan pencapaian akademik. Selain itu juga, kajian grit mempunyai kelebihan dari sudut kemampuan ia untuk menjadi faktor peramal kepada kesejahteraan subjektif (Jeong \& Jin, 2020; Jiang et al., 2020; Moen \& Olsen, 2020).

Dalam kajian ini, penyelidik ingin mengetahui tahap kesejahteraan subjektif pelajar dan tahap personaliti grit dalam kalangan pelajar memandangkan pelajar telah mengikuti pembelajaran norma baharu lebih dari setahun. Hasil daripada kajian ini penting untuk mengetahui keadaan dan tahap kesejahteraan pelajar. Pada masa yang sama, kajian ini bertujuan untuk melihat hubungan antara 
personaliti grit dengan kesejahteraan subjektif dalam kalangan pelajar sarjana muda, pelajar sarjana dan pelajar doktor falsafah di UKM. Secara lebih spesifik, objektif kajian adalah:

i. Mengenal pasti tahap kesejahteraan subjektif pelajar dan tahap personaliti grit

ii. Mengenal pasti hubungan antara personaliti grit terhadap kesejahteraan subjektif pelajar

iii. Mengenal pasti sama ada personaliti grit mampu meramal kesejahteraan subjektif pelajar

\section{Sorotan Literatur}

\section{Kesejahteraan Subjektif Pelajar}

Menurut Kahneman dan Krueger (2006), kesejahteraan subjektif secara umumnya adalah hasil seseorang individu menilai peristiwa atau pengalaman hidup serta emosi yang dirasainya sama ada perasaan positif atau negatif (contoh: perasaan tenang, tertekan, bahagia dan marah). Menurut Diener (1984) kesejahteraan subjektif adalah penting dalam meningkatkan kualiti kehidupan. Kualiti kehidupan yang baik dapat dipertingkatkan sekiranya individu mengalami pengalaman yang positif yang banyak dan pengalaman negatif yang sedikit. Selain itu, kesejahteraan subjektif juga dilihat sebagai satu instrumen yang lebih komprehensif dalam mengukur tahap kualiti kehidupan kerana aspek ini tidak memfokuskan komponen materialistik dalam mengukur kebahagiaan, akan tetapi mengambil kira perspektif individu dalam menilai kebahagiaan.

Oleh itu, kajian ini ingin memfokuskan perspektif pelajar dalam menilai kualiti pembelajaran dalam talian di sepanjang musim pandemik. Menurut Renshaw dan Bolognino (2016) kesejahteraan subjektif pelajar adalah penilaian pelajar terhadap empat aspek iaitu kepuasan terhadap pencapaian akademik (academic satisfaction), kesyukuran terhadap pendidikan yang dijalani (college grattitude), keterhubungan dengan institusi pendidikan (school connectedness), dan keberkesanan akademik (academic efficacy),

Aspek 'keberkesanan akademik' menurut Renshaw dan Bolognino (2016) menerangkan keyakinan individu dalam menyelesaikan sebarang tugas yang spesifik termasuklah tugas-tugas akademik. Aspek ini juga memberikan gambaran terhadap penilaian positif serta keyakinan pelajar terhadap sikap kerja serta kemampuan kognitif dalam menghadapi pembelajaran dalam talian semasa wabak pandemik. Aspek kesejahteraan yang kedua iaitu 'kepuasan terhadap pencapaian akademik' pula menilai kualiti kehidupan di alam pembelajaran (Renshaw \& Bolognino, 2016). Kepuasan yang dinilai merujuk kepada pengalaman akademik, proses pembelajaran yang dilalui dan prestasi yang diperolehi daripada pembelajaran semasa PKP. Aspek kesejahteraan subjektif oleh Renshaw dan Bolognino (2016) yang ketiga ialah 'keterhubungan dengan institusi pendidikan' yang menggambarkan persepsi yang dibina oleh pelajar terhadap hubungan yang harmoni dalam pengalaman hidupnya sebagai seorang pelajar. Keterikatan diri dengan kehidupan di universiti dapat dilihat apabila pelajar merasakan dirinya adalah sebahagian dari lingkungan sosial universiti yang meliputi pensyarah dan rakan-rakan. Akhir sekali, aspek yang keempat iaitu 'kesyukuran terhadap pendidikan yang dijalani' pula menggambarkan respons emosi pelajar ketika mendapatkan manfaat daripada lingkungan luaran. Dalam aspek ini, kesyukuran berkait dengan respons emosi pelajar apabila dapat melanjutkan pendidikan di peringkat tertinggi, dapat bantuan dan sokongan daripada rakan sekelas dan peluang untuk mempelajari ilmu baharu. Dalam kajian ini, keempat-empat aspek ini akan diukur bagi memberikan gambaran terhadap kesejahteraan subjektif pelajar dalam mengharungi proses pembelajaran dalam talian sepanjang wabak Covid-19.

Dalam konteks pelajar di universiti, kajian berkenaan subjektif kebanyakan menyentuh aspek kesihatan mental, kecerdasan spiritual, demografi, harga diri, kawalan kendiri, pencapaian akademik dan emosi (Ariati, 2010; Daud et al., 2020). Muhammad Salehan et al. (2020) turut menggemukkan beberapa model kebahagiaan hidup melalui beberapa pendekatan teori termasuklah teori kesejahteraan subjektif oleh Diener (1984).

Teori Kesejahteraan Subjektif Diener (1984) merangkumi 5 komponen iaitu, faktor kognitif, faktor sikap, faktor kontekstual, reaksi emosional dan kualiti kehidupan dalam menghuraikan pengalaman 
DOI: https://doi.org/10.47405/mjssh.v6i9.980

hidup individu. Faktor kognitif merangkumi pertimbangan akal dalam menilai peristiwa hidup yang berlaku. Manakala faktor sikap pula mengaitkan ciri keperibadian, tahap kesihatan mental serta personaliti seseorang individu. Faktor kontekstual merujuk kepada faktor pengalaman hidup individu dan faktor sosiodemografi yang secara tidak langsung memberi kesan terhadap kesejahteraan subjektif. Kualiti kehidupan pula merujuk kepada kepuasan yang dialami oleh individu secara keseluruhan berdasarkan faktor personaliti, ciri keperibadian, serta tahap kesihatan mental dan emosi. Reaksi emosi pula merujuk kepada reaksi yang dipamerkan oleh individu sama ada secara positif atau negatif (Diener 1984).

Rajah 1 di bawah memaparkan bagaimana kesejahteraan subjektif dipengaruhi oleh faktor kognitif, faktor sikap serta faktor kontekstual.

Rajah 1: Teori Kesejahteraan Subjektif oleh Diener (1984)

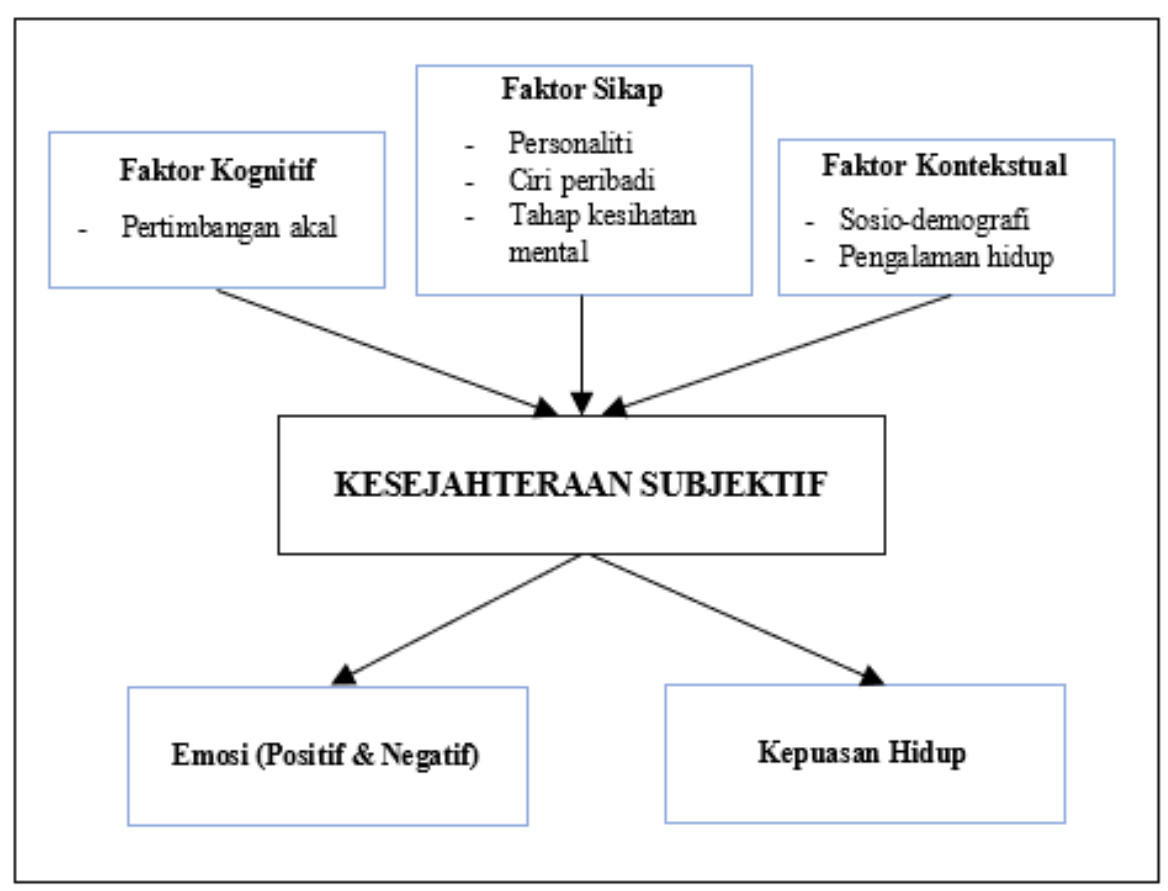

Teori ini turut menjelaskan pengalaman positif dan negatif yang dialami oleh seseorang individu dinilai secara kognitif iaitu pertimbangan akal dan ia memberi kesan terhadap kesejahteraan psikologi individu.

Menurut Ariati (2010), proses pembentukan kesejahteraan subjektif ini melibatkan penilaian terhadap pengalaman hidup yang didorong oleh personaliti, keyakinan diri dan persepsi seseorang individu. Melalui pendekatan grit, dapat dijelaskan bahawa terdapat pengaruh minat yang mendalam serta kecekalan usaha memberi kesan terhadap penilaian individu dalam menilai sesuatu perkara yang berlaku dalam hidupnya (Duckworth et al., 2007). Menurutnya lagi, pengalaman pembelajaran yang positif dapat diwujudkan melalui sikap kegigihan pelajar untuk mencapai matlamat yang diharapkan serta kecekalan usaha dalam mengekalkan minat dalam jangka waktu yang panjang.

Nora Izaach (2017) serta Renshaw dan Bolognino (2016) turut menyatakan bahawa pembentukan personaliti berkait rapat terhadap kesejahteraan subjektif pelajar kerana personaliti serta pengalaman pembelajaran memberi kesan terhadap kepuasan dan kesejahteraan hidup. Merujuk kepada Kesejahteraan Subjektif Diener (1984), aspek personaliti turut menjadi faktor kepada pembentukan kesejahteraan subjektif. Dalam konteks personaliti grit, beberapa kajian lain telah membuktikan bahawa terdapat hubungan diantara grit dan kesejahteraan subjektif (Arya \& Lal, 2018; Jeong \& Jin, 2020; Jiang et al., 2020). Oleh itu, teori ini merupakan teori yang mendasari kajian ini. 
Memandangkan pelajar kini sedang menghadapi cabaran yang besar dalam mengikuti pembelajaran dalam talian serta berhadapan cabaran untuk melangsungkan hidup dalam keadaan pandemik ini, aspek kesejahteraan subjektif penting untuk dinilai kerana aspek ini merupakan salah satu petunjuk dalam menilai kepuasan hidup serta kesihatan mental pelajar. Secara kesimpulan, kajian berkenaan kesejahteraan subjektif adalah penting untuk dikaji, dan diterokai dalam kalangan pelajar agar dapat kita mengenal pasti tahap kesejahteraan subjektif pelajar terkini.

\section{Personaliti Grit}

Grit diperkenalkan oleh (Duckworth et al., 2007) yang merujuk kepada personaliti atau tret seseorang individu yang mempunyai ketabahan menghadapi cabaran dan mengalami semangat yang tinggi untuk mencapai matlamat jangka panjang. Duckworth et al. (2007) juga menyatakan bahawa grit dapat dilihat melalui semangat dalam mencapai matlamat jangka panjang dan tingkah laku untuk meningkatkan ketekunan walaupun dilanda cabaran. Bersesuaian dengan isu semasa, pandemik Covid-19 memberikan kesan dan cabaran dari pelbagai aspek kehidupan. Pelajar juga turut terkesan dengan cabaran untuk mengikuti proses pembelajaran bagi mencapai kejayaan dalam bidang yang diceburinya.

Terdapat dua dimensi grit menurut Duckworth et al. (2007) iaitu: a) minat yang konsisten (Consistency of Interest); b) ketahanan atau ketekunan dalam berusaha (Perseverance of Effort). Dimensi minat yang konsisten (Consistency of Interest) merujuk kepada kemampuan untuk mengekalkan minat pada satu tujuan. Individu yang mempunyai minat yang konsisten tinggi tidak akan mengubah tujuan yang telah ditetapkan, mempunyai fokus, dan mampu mengekalkan minat dalam waktu yang panjang (Duckworth et al., 2007). Dimensi ketahanan atau ketekunan dalam berusaha (Perseverance of Effort) pula merujuk kepada individu tidak takut untuk menghadapi tentangan atau halangan dalam mencapai cita-cita serta bekerja keras secara bersungguh-sungguh mencapai matlamat jangka panjangnya. Individu yang memiliki ketekunan dalam berusaha akan mampu menghadapi halangan serta mampu menyelesaikan urusan yang sedang dilalui. Ketekunan yang dimiliki menjadikan diri tidak takut untuk menghadapi tentangan dalam mencapai matlamat jangka masa panjang (Duckworth et al., 2007).

Individu yang mempunyai grit yang tinggi tidak akan mengubah haluan atau mengalah apabila didatangi perasaan kecewa atau bosan terhadap sesuatu perkara. Mereka akan tetap berusaha dan kekal pada jalan yang dipilihnya (Duckworth et al., 2007). Sejajar dengan penjelasan ini, Nora (2017) menjelaskan bahawa pelajar yang mempunyai tahap personaliti grit mempunyai potensi yang tinggi untuk mencapai tujuan hidup dan kejayaan yang diingini.

Menurut Lam dan Zhou (2019), kajian berkenaan topik personaliti grit dikaji secara meluas di negara Barat seperti Amerika Syarikat. Negara Asia seperti Korea dan China konteks remaja sekolah dan pelajar universiti (Jeong \& Jin, 2020; Jiang et al., 2020). Kajian ini turut membuktikan bahawa personaliti grit dapat meningkatkan pencapaian akademik serta kesejahteraan subjektif pelajar universiti. Walau bagaimanapun, kajian terkini berkenaan personaliti grit terhadap pelajar universiti di Malaysia masih belum diterokai sepenuhnya namun terdapat beberapa kajian berkenaan grit oleh Azlin dan Mohamad (2019) yang berkaitan dengan prestasi dan kesejahteraan psikologi. Azlin dan Mohamad (2019) mencadangkan kajian berkenaan personaliti grit perlu dikembangkan lagi berikutan topik ini masih belum meluas di Malaysia. Kesimpulannya, penyelidikan berkenaan personaliti grit adalah penting untuk dikaji bagi mengisi jurang pengetahuan berkenaan topik ini.

\section{Personaliti Grit dan Kesejahteraan Subjektif Pelajar Universiti}

Personaliti grit turut dikaji dalam populasi yang berbagai dalam melihat hubungannya terhadap kesejahteraan subjektif seseorang individu. Beberapa kajian berkenaan kesejahteraan subjektif telah dikaji meliputi aspek keperluan asas psikologi (basic psychological need) dalam kalangan remaja Korea dan China (Jeong \& Jin, 2020); keperluan asas kepuasan hidup (basic satisfaction need) dan kesejahteraan subjektif dalam kalangan populasi Korea dan remaja China (Jiang et al., 2020; Jin \& Kim, 2017; Li et al., 2018); keprihatinan (mindfulness) dalam kalangan populasi China (Li et al. 2018); tekanan pekerjaan dalam kalangan siswazah Korea (Lee, 2018); kesejahteraan dan fenomena alih (burnout) dalam kalangan jurulatih sukan Norway (Moen \& Olsen, 2020); respons daya tindak 
terhadap kegagalan dalam kalangan pelajar atlet di New York (Hayden, 2018); dan daya tahan dalam kalangan pelajar di Australia (Calo et al., 2019). Kajian yang dikenal pasti ini telah dijalankan dalam populasi Asia, dapatan kolektif tersebut secara konsisten menunjukkan grit mempunyai hubungan yang tersendiri terhadap pelbagai aspek. Secara keseluruhan, kajian-kajian yang dinyatakan membuktikan bahawa mereka yang memunyai tahap grit yang tinggi membantu dalam meningkatkan kesejahteraan subjektif individu. Walaupun begitu, kajian-kajian ini tidak menguji grit sebagai konstruk mandiri dalam melihat hubungan kesejahteraan subjektif pelajar semasa mengikuti pembelajaran sepanjang musim wabak Covid-19.

Seperti yang telah dijelaskan berkenaan personaliti grit, ketekalan minat dan ketekunan berusaha merupakan faktor sikap yang dapat meningkatkan kepuasan hidup melalui pembentukan persepsi yang positif dan semangat diri dalam menghadapi cabaran (Duckworth et al., 2007). Selain itu juga, Datu (2017) turut menjelaskan bahawa kecekalan usaha dalam grit memberi kesan peningkatan emosi positif dan pengurangan emosi negatif. Selari dengan teori Kesejahteraan Subjektif oleh Diener (1984), aspek personaliti merupakan faktor penyumbang kepada pembentukan emosi positif dan pengurangan emosi negatif dalam meningkatkan kesejahteraan subjektif individu.

Selain itu, kajian oleh Arya dan Lal (2018), Jeong dan Jin (2020) serta Jiang et al. (2020) telah membuktikan bahawa terdapat hubungan positif antara grit dan kesejahteraan subjektif. Berdasarkan kajian tersebut, pelajar yang mempunyai tahap grit yang tinggi mampu meningkatkan tahap kesejahteraan subjektif. Walau bagaimanapun, terdapat juga sebuah kajian yang mendapati salah satu domain bagi grit iaitu ketekalan minat (Consistency of interest) mempunyai hubungan negatif yang lemah terhadap kesejahteraan subjektif (Disabato et al., 2019). Oleh itu, Disabato et al. (2019) mencadangkan kajian lanjutan berkenaan grit perlu diperluaskan memandangkan sebahagian konsep grit masih belum dijelaskan hubungannya terhadap kesejahteraan subjektif.

Berdasarkan sorotan literatur, kajian mengenai personaliti grit terhadap kesejahteraan subjektif pelajar masih belum diterokai sepenuhnya dalam konteks pelajar di Malaysia (Azlin \& Mohamad, 2019; Lam \& Zhou, 2019). Perkara ini mendorong penyelidik untuk menjalankan kajian bagi menerokai tahap personaliti grit serta hubungannya terhadap kesejahteraan subjektif pelajar Universiti Kebangsaan Malaysia.

\section{Metod Kajian}

\section{Reka Bentuk Kajian}

Penyelidikan ini adalah kajian kuantitatif menggunakan reka bentuk kaedah tinjauan. Menurut Crawford dan Irving (2009) reka bentuk tinjauan adalah kaedah yang bersesuaian bagi kajian penerokaan. Oleh itu, kaedah ini bersesuaian dengan penyelidikan ini kerana objektif kajian ini adalah untuk meneroka tahap grit dan kesejahteraan subjektif serta hubungan di antara kedua-dua konstruk. Selain itu juga, Rozmi (2013) menyatakan kaedah tinjauan berbentuk survei merupakan kaedah yang mampu memerihalkan dan meneroka populasi yang ingin dikaji dengan mendapatkan maklumat daripada sejumlah responden bagi mewakili populasi.

\section{Pemilihan Sampel}

Kaedah persampelan secara rawak berkelompok telah digunakan dalam memilih pelajar Universiti Kebangsaan Malaysia yang mempunyai populasi seramai 33,983 orang pelajar secara keseluruhan yang meliputi 14 fakulti. Seperti yang dicadangkan oleh Cohen, Manion dan Morrison (2001), saiz sampel yang melebihi 25000 orang memerlukan sampel responden sebanyak 378 orang dengan ralat persampelan sebanyak 5\% dan aras keyakinan 95\%. Sejumlah 387 orang pelajar universiti terlibat sebagai responden kajian.

\section{Pengumpulan Data}


Kajian ini mengedarkan soal selidik secara dalam talian dengan menggunakan Google Form berikutan kekangan pandemik Covid-19 yang melanda. Soal selidik kajian personaliti grit daripada Short Grit Scale (Grit-S) oleh Duckworth dan Quinn (2009) yang mempunyai 8 item dan soal selidik College Student Subjective Wellbeing Questionnaire oleh Renshaw (2018) yang mempunyai 17 item telah digunakan. Soal selidik mempunyai tiga bahagian iaitu: a) Bahagian A: Demografi; b) Bahagian B: Tahap personaliti grit; c) Bahagian C: Tahap kesejahteraan subjektif pelajar. Item di bahagian B berbentuk skala liket 5 mata dari skor 1 mewakili pernyataan 'Sangat menggambarkan saya' hingga skor 5 mewakili pernyataan 'Sangat tidak menggambarkan diri saya' manakala item di bahagian C berbentuk skala likert 7 mata dari skor 1 mewakili pernyataan 'Sangat tidak bersetuju' hingga ke skor 7 mewakili pernyataan 'Sangat bersetuju'. Skor bagi setiap skala dan sub skala dikira berdasarkan nilai min item dalam skala dan sub skala. Sebelum responden terpilih menjawab soal selidik, mereka turut dijelaskan berkenaan tujuan kajian serta kriteria responden kajian iaitu pelajar UKM yang masih mengikuti pengajian. Setelah itu responden diminta untuk melengkapkan kesemua ruangan pilihan jawapan dalam soal selidik.

\section{Kesahan dan Kebolehpercayaan}

Kesahan konstruk telah dilakukan bagi mengetahui sejauh mana suatu alat ukuran itu dapat mengukur sesuatu konstruk. Dalam kajian ini, soal selidik asli telah diterjemahkan ke dalam bahasa Melayu serta disemak oleh dua orang pakar dalam bahasa Melayu dan bahasa Inggeris. Setelah itu, soal selidik diserahkan kepada dua orang penilai yang pakar yang merupakan pensyarah dalam bidang psikologi. Proses ini bertujuan untuk memastikan instrumen yang digunakan mengukur konstruk dengan tepat dan benar (Cohen, Manion, and Morrison 2013). Penambahbaikan dilakukan setelah disemak oleh panel pakar. Instrumen yang diluluskan boleh melalui fasa yang seterusnya iaitu kajian rintis. Kajian rintis dijalankan bagi menilai kebolehpercayaan sesuatu item dengan menganalisis nilai signifikan Cronbach Alpha. Ukuran nilai yang lazim adalah bernilai 0.6 hingga 0.8. Nilai Alpha yang terbaik adalah 0.8 dan ke atas (Nunnally, 1978). Tambahan pula, Kerlinger (1975) menyatakan bahawa sesebuah kajian yang mempunyai kesahan yang amat tinggi mempunyai ciri yang stabil, ketekalan, ramalan, dan ketepatan.

Hasil kajian rintis terhadap 81 orang responden mencatatkan nilai kebolehpercayaan, $\alpha$ bagi instrumen personaliti grit adalah 0.576 manakala instrumen kesejahteraan subjektif pelajar adalah 0.941 . Menurut Perry et al. (2004) nilai kebolehpercayaan di antara 0.5 hingga 0.7 menunjukkan bahawa instrumen mempunyai tahap kebolehpercayaan yang sederhana manakala kebolehpercayaan yang tinggi mempunyai nilai 0.8 dan ke atas.

Secara keseluruhan, kebolehpercayaan instrumen kajian ini mempunyai nilai pekali Cronbach yang tinggi bagi setiap konstruk. Berikut adalah jadual yang merumuskan nilai pekali Cronbach bagi setiap konstruk kajian ini.

Jadual 1: Jadual Kebolehpercayaan Instrumen Kajian

\begin{tabular}{lcccc}
\hline Konstruk & n & Bil. Item & Cronbach's Alpha & Sisihan Piawai \\
\hline Personaliti grit & 387 & 8 & 0.906 & 6.9312 \\
Kesejahteraan Subjektif & 387 & 17 & 0.957 & 18.1021 \\
\hline
\end{tabular}

\section{Kaedah Penganalisisan Data}

Kajian ini menggunakan perisian SPSS versi 23.0 untuk menganalisis data deskriptif dan inferensi. Analisis deskriptif melibatkan nilai kekerapan, peratusan, min serta sisihan piawai manakala analisis inferensi pula menggunakan analisis parametrik Ujian Korelasi Pearson dan regresi (Julie, 2013). Bagi analisis deskriptif, penginterpretasian skor min bagi skala likert 5 mata akan merujuk kepada Jadual 2 di bawah bagi menilai tahap personaliti grit dalam kalangan pelajar.

Jadual 2: Pengelasan Julat Min Skor bagi Tahap Personaliti Grit 


\begin{tabular}{cc}
$4.01-5.00$ & Tinggi \\
$3.01-4.00$ & Sederhana Tinggi \\
$2.01-3.00$ & Sederhana Rendah \\
$1.00-2.00$ & Rendah \\
\hline
\end{tabular}

Sumber: Nunnally dan Bernstein (1994)

Bagi menilai tahap kesejahteraan subjektif yang berskala 7 mata, pengelasan julat min skor yang digunakan adalah seperti yang dipamerkan di bawah (Jadual 3).

Jadual 3: Pengelasan Julat Min Skor bagi Tahap Kesejahteraan Subjektif

\begin{tabular}{cc}
\hline Julat skor & Tahap \\
\hline $5.01-7.00$ & Tinggi \\
$3.01-5.00$ & Sederhana \\
$1.00-3.00$ & Rendah \\
\hline
\end{tabular}

Sumber: Adaptasi daripada Nik Mohd (2004)

Analisis Korelasi Pearson pula akan digunakan sebagai analisis inferensi bagi melihat hubungan diantara pemboleh ubah personaliti grit terhadap kesejahteraan subjektif pelajar. Menurut Cohen (1998), kekuatan bagi hubungan antara pemboleh ubah boleh di interpretasi berdasarkan nilai pekali korelasi, r. Jadual 4 di bawah merupakan julat bagi nilai pekali korelasi serta interpretasi kekuatannya.

Jadual 4: Interpretasi Pekali Korelasi

\begin{tabular}{cc}
\hline Nilai pekali korelasi & Kekuatan hubungan \\
\hline $0.50-1.00$ & Kuat \\
$0.30-0.49$ & Sederhana \\
$0.10-0.29$ & Lemah \\
\hline
\end{tabular}

Sumber: Cohen (1988)

\section{Hasil Kajian}

\section{Profil Demografi}

Analisis ini akan membentangkan profil responden kajian ini. Jadual 5 menunjukkan profil responden berdasarkan maklumat demografi. Jumlah keseluruhan responden yang terlibat adalah seramai 387 orang. Jadual di bawah menunjukkan taburan demografi responden.

Jadual 5: Maklumat Demografi

\begin{tabular}{llcc}
\hline Demografi & & Bil. & Peratus (\%) \\
\hline \multirow{2}{*}{ Jantina } & Lelaki & 82. & 21.2 \\
& perempuan & 305 & 78.8 \\
\multirow{3}{*}{ Kaum } & Melayu & 294 & 76.0 \\
& Cina & 52 & 13.4 \\
& India & 35 & 9.0 \\
\multirow{3}{*}{ Peringkat pengajian } & Lain-lain & 6 & 1.6 \\
& Ijazah sarjana muda & 244 & 63.0 \\
& Ijazah sarjana & 107 & 27.6 \\
& Pasca siswazah & 36 & 9.3 \\
\hline
\end{tabular}




\section{Tahap Grit dan Kesejahteraan Subjektif Pelajar}

Analisis seterusnya akan melihat kepada Tahap grit dan kesejahteraan subjektif pelajar. Jadual 6 memaparkan skor min secara keseluruhan bagi tahap personaliti grit dalam kalangan pelajar universiti. Berdasarkan jadual dapat dilihat bahawa Tahap skor personaliti grit secara keseluruhan bagi pelajar UKM adalah sederhana tinggi dengan nilai $\min =3.51$, s.p. $=0.866$. Hasil kajian ini juga menunjukkan bahawa dimensi bagi konstruk personaliti grit yang tertinggi adalah Ketekunan berusaha $(\mathrm{min}=3.60$, s.p. $=0.930697)$, diikuti oleh dimensi Ketekalan minat $(\min =3.43$, s.p. $=0.987)$. Kedua-dua dimensi berada pada tahap sederhana tinggi.

Jadual 6: Tahap Personaliti Grit

\begin{tabular}{lccc}
\hline & Min & S.P. & Tahap \\
\hline Ketekalan minat (Consistency of Interest) & 3.43 & 0.987 & Sederhana Tinggi \\
Ketekunan berusaha (Perseverance of Effort) & 3.60 & 0.931 & Sederhana Tinggi \\
\hline Keseluruhan Konstuk (Personaliti grit) & $\mathbf{3 . 5 1}$ & $\mathbf{0 . 8 6 6}$ & Sederhana Tinggi
\end{tabular}

Jadual 7 menunjukkan skor min secara keseluruhan bagi tahap Kesejahteraan Subjektif Pelajar dalam kalangan pelajar UKM. Berdasarkan jadual dapat dilihat bahawa Tahap skor Kesejahteraan Subjektif Pelajar secara keseluruhan adalah tinggi dengan nilai $\min =5.09$, s.p. $=1.064$. Hasil kajian ini juga menunjukkan bahawa dimensi bagi konstruk kesejahteraan pelajar yang tertinggi adalah Kesyukuran terhadap pendidikan yang dijalani $(\min =5.89$, s.p. $=0.891)$, diikuti oleh dimensi Kepuasan terhadap pencapaian akademik $(\min =5.04$, s.p. $=1.250)$. Seterusnya, dimensi Keterhubungan dengan institusi pendidikan $(\min =4.83$, s.p. $=1.218)$ dan akhir sekali ialah dimensi Keberkesanan akademik $(\mathrm{min}=$ 4.70, s.p. $=1.343)$.

Jadual 7: Tahap Kesejahteraan Subjektif Pelajar

\begin{tabular}{llll}
\hline & Min & S.P. & Tahap \\
\hline $\begin{array}{l}\text { Kepuasan terhadap pencapaian akademik } \\
\text { (academic satisfaction) }\end{array}$ & 5.04 & 1.250 & Tinggi \\
$\begin{array}{l}\text { Keberkesanan akademik (academic efficacy) } \\
\begin{array}{l}\text { Keterhubungan institusi pendidikan (school } \\
\text { connectedness) }\end{array}\end{array}$ & 4.70 & 1.343 & Sederhana \\
$\begin{array}{l}\text { Kesyukuran terhadap pendidikan yang dijalani } \\
\text { (college grattitude) }\end{array}$ & 5.89 & 1.218 & Sederhana \\
\hline $\begin{array}{l}\text { Keseluruhan Konstruk } \\
\text { Kesejahteraan Subjektif Pelajar) }\end{array}$ & $\mathbf{5 . 0 9}$ & $\mathbf{1 . 0 6 4}$ & Tinggi \\
\hline
\end{tabular}

\section{Hubungan antara Personaliti Grit dengan Kesejahteraan Subjektif Pelajar}

\section{Ho1: Tidak terdapat hubungan yang signifikan antara personaliti grit dengan kesejahteraan subjektif pelajar.}

Jadual 8 di bawah memaparkan keputusan pengujian hipotesis bagi mengenal pasti hubungan di antara pemboleh ubah personaliti grit dan Kesejahteraan Subjektif pelajar. Hasil analisis korelasi Pearson menunjukkan dimensi Ketekalan minat mempunyai hubungan signifikan yang lemah $(r=0.242, p<$ 0.01) manakala dimensi ketekunan usaha menunjukkan hubungan yang signifikan yang kuat $(r=0.409$, $\mathrm{p}<0.01)$. Personaliti grit secara keseluruhan mempunyai hubungan sederhana kuat yang terhadap kesejahteraan subjektif pelajar $(\mathrm{r}=0.357, \mathrm{p}<0.01)$. Hubungan yang ditunjukkan adalah signifikan. Oleh itu, hipotesis nol gagal diterima. 
Jadual 8: Hubungan antara Personaliti grit dengan Kesejahteraan Subjektif Pelajar

\begin{tabular}{lcc} 
& \multicolumn{2}{c}{ Kesejahteraan Subjektif Pelajar } \\
\cline { 2 - 3 } & $\mathbf{r}$ & Sig. $\mathbf{p}$ \\
\hline Ketekalan Minat & $0.242^{* *}$ & 0.000 \\
Ketekunan Usaha & $0.409^{* *}$ & 0.000 \\
\hline Keseluruhan Personaliti grit & $\mathbf{0 . 3 5} 7^{* *}$ & $\mathbf{0 . 0 0 0}$ \\
\hline$* * \mathrm{p}<0.01$ & &
\end{tabular}

\section{Analisis Regresi Personaliti Grit dengan Kesejahteraan Subjektif Pelajar}

Ho2: Tiada ramalan yang signifikan untuk tahap kesejahteraan subjektif pelajar oleh personaliti grit.

Berdasarkan jadual di bawah, dapat dilihat bahawa korelasi (R) di antara dua pemboleh ubah adalah rendah (0.357). Nilai $\mathrm{R}^{2}$ dilaraskan $=0.125$ menunjukkan bahawa personaliti grit menyumbang $12.5 \%$ daripada varians tahap kesejahteraan subjektif pelajar.

Jadual 9: Ringkasan Model

\begin{tabular}{ccccc} 
Model & $\mathbf{R}$ & $\mathbf{R}^{\mathbf{2}}$ & $\mathbf{R}^{\mathbf{2}}$ dilaraskan & S.P. \\
\hline 1 & $0.357_{\mathrm{a}}$ & 0.128 & 0.125 & 0.99578 \\
\hline
\end{tabular}

a. Peramal: (Konstant), Personaliti grit

Jadual ANOVA (Jadual 10) menunjukkan Statistik F yang signifikan $(\mathrm{p}=0.000)$. Ujian regresi mudah menunjukkan personaliti grit mempunyai hubungan yang signifikan dengan Kesejahteraan Subjektif Pelajar, $\mathrm{F}(1,385)=56.384, \mathrm{p}<0.001$, dengan nilai $\mathrm{R}^{2}$ dilaraskan $=0.125$.

Jadual 10: Jadual ANOVA ${ }^{a}$

\begin{tabular}{cccccc}
\hline Model & Jumlah pekali dua & df & Min $^{2}$ & F & Sig. \\
\hline Regresi & 55.909 & 1 & 55.909 & 56.384 & $0.000_{\mathrm{b}}$ \\
Residual & 381.759 & 385 & 0.992 & & \\
Jumlah & 437.669 & 386 & & & \\
\hline
\end{tabular}

a. Pemboleh ubah bersandar: Kesejahteraan Subjektif Pelajar

b. Peramal: (Konstant), Personaliti grit

Berdasarkan jadual di bawah (Jadual 11) sebuah persamaan linear seperti di bawah boleh dibina berdasarkan nilai pekali tidak piawai (Unstandardized Coefficients):

$$
\mathrm{y}=\mathrm{c}+\mathrm{b}(\mathrm{x})
$$

$\mathrm{y}=$ nilai skor kesejahteraan subjektif pelajar yang dianggarkan

$\mathrm{c}=$ nilai pemalar $($ intercept $)$

$\mathrm{b}=$ nilai pekali regresi (Personaliti grit)

$\mathrm{x}=$ nilai skor pemboleh ubah peramal ( pemboleh ubah tidak bersandar)

Jadual 11: Jadual Pekali ${ }^{a}$

\begin{tabular}{|c|c|c|c|c|c|}
\hline \multirow{2}{*}{ Model } & \multicolumn{2}{|c|}{ Pekali tidak piawai } & \multirow{2}{*}{$\begin{array}{c}\text { Pekali piawai } \\
\text { Beta }\end{array}$} & \multirow{2}{*}{$\mathbf{t}$} & \multirow{2}{*}{ Sig. } \\
\hline & B & Std. Error & & & \\
\hline (Konstant) & 3.547 & 0.212 & & 16.754 & 0.000 \\
\hline Personaliti grit & 0.439 & 0.058 & 0.357 & 7.509 & 0.000 \\
\hline
\end{tabular}

a. Pemboleh ubah bersandar: Kesejahteraan Subjektif 
Berdasarkan jadual di atas, terdapat pengaruh yang signifikan antara personaliti grit dengan Kesejahteraan Subjektif Pelajar dengan menggunakan persamaan regresi berikut:

$$
\text { Kesejahteraan subjektif pelajar }=3.547+(0.439 \times \text { Personaliti grit })
$$

Jangkaan Kesejahteraan Subjektif adalah 3.547 + 0.439X. Berdasarkan persamaan ini, Tahap Kesejahteraan Subjektif Pelajar akan meningkat sebanyak 0.439 bagi setiap tahap personaliti grit. Ujian regresi mudah menunjukkan personaliti grit mempunyai hubungan yang signifikan dengan Kesejahteraan Subjektif Pelajar, F $(1,385)=56.384$, $\mathrm{p}<0.001$, dengan nilai R2 dilaraskan $=0.125$. Hasil analisis regresi linear ini memaparkan model yang dibina mempunyai nilai $F$ yang signifikan $(\mathrm{p}<$ 0.01). Perkara ini menunjukkan bahawa personaliti grit dapat menyumbang $12.5 \%$ terhadap varian Kesejahteraan subjektif pelajar secara kolektif. Oleh itu, hipotesis nol gagal diterima. personaliti grit meramalkan secara signifikan untuk tahap kesejahteraan subjektif pelajar.

Secara kesimpulan kepada dapatan kajian ini, pelajar UKM mempunyai tahap personaliti grit yang sederhana tinggi dan tahap kesejahteraan subjektif yang tinggi. Berdasarkan ujian korelasi, dapatan kajian membuktikan bahawa terdapat hubungan signifikan di antara personaliti grit terhadap kesejahteraan subjektif pelajar. Analisis regresi juga membuktikan personaliti grit mampu meramal tahap kesejahteraan subjektif pelajar dengan signifikan. Secara keseluruhan, kajian ini telah menguji kedua-dua hipotesis kajian dan kedua-dua hipotesis nol ditolak. Jadual di bawah menunjukkan rumusan bagi keputusan hipotesis nol.

Jadual 12: Rumusan hipotesis

\begin{tabular}{llc}
\hline & \multicolumn{1}{c}{ Hipotesis } & Keputusan \\
\hline Ho1 & $\begin{array}{l}\text { Tidak terdapat hubungan yang signifikan antara personaliti grit dengan } \\
\text { tahap kesejahteraan subjektif pelajar }\end{array}$ & Ditolak \\
Ho2 & $\begin{array}{l}\text { Tiada ramalan yang signifikan untuk tahap kesejahteraan subjektif } \\
\text { pelajar oleh personaliti grit }\end{array}$ & Ditolak \\
\hline
\end{tabular}

\section{Perbincangan Kajian}

Berdasarkan hasil kajian di atas, dapat dilihat terdapat beberapa perbezaan dapatan kajian ini dengan kajian yang terdahulu yang menunjukkan tahap personaliti yang tinggi (Arya \& Lal, 2018; Jeong \& Jin, 2020; Jiang et al., 2020) manakala hasil kajian ini pula menunjukkan pelajar universiti mempunyai tahap personaliti grit yang sederhana tinggi serta mempunyai tahap ketekunan usaha dan ketekalan minat yang sederhana tinggi. Perkara ini menjelaskan bahawa pelajar UKM masih mempunyai ketabahan menghadapi cabaran dan mengalami semangat yang tinggi untuk mencapai matlamat jangka panjang (Duckworth et al. 2007). Tahap personaliti grit yang sederhana tinggi ini membuktikan bahawa walaupun pelajar dilanda cabaran dan rintangan, mereka mampu mempertahankan tingkah laku ketekunan dan semangat dalam mencapai matlamat jangka panjang. Kenyataan in dijelaskan oleh Duckworth et al. (2007) berkenaan ciri dan tingkah laku seseorang individu yang mempunyai personaliti grit. Selain itu, dapatan kajian ini juga disokong oleh Septania (2020) menjelaskan bahawa terdapat lima faktor strategi kelangsungan hidup pelajar dalam mengharung pandemik Covid-19 iaitu: ketekalan, usaha mengekalkan matlamat, menghadapi cabaran, melaksanakan tugas dan kerja keras..

Selain itu, dapatan kajian ini memberikan gambaran bahawa pelajar universiti di UKM mempunyai kebolehan untuk menyesuaikan pembelajarannya dengan baik. Walau bagaimanapun, nilai min skor bagi kesejahteraan subjektif pelajar dalam kajian ini tidak berada pada tahap yang sangat tinggi. Perkara ini mungkin dapat dijelaskan berdasarkan min skor bagi pecahan dimensi kesejahteraan subjektif pelajar yang menunjukkan bahawa dimensi keberkesanan (academic efficacy), dan keterhubungan dengan institusi pendidikan (school connectedness) mempunyai tahap yang sederhana. 
Namun begitu, dimensi kepuasan terhadap pencapaian akademik (academic satisfaction) dan kesyukuran terhadap pendidikan yang dijalani (college grattitude) menunjukkan pelajar UKM mempunyai kepuasan dalam pengalaman pembelajaran, serta berasa syukur ketika mendapatkan manfaat daripada proses pembelajaran. Bertepatan dengan Teori Kesejahteraan Subjektif Diener (1984), peningkatan tahap kesejahteraan pelajar adalah disebabkan kemampuan pelajar untuk meningkatkan pengalaman positif dalam pembelajaran melalui reaksi tingkah laku bersyukur, yakin serta berasa puas terhadap pengalaman pembelajaran.

Selain itu, dapatan kajian ini selari dengan Moen dan Olsen (2020) serta Septania (2020) yang menunjukkan bahawa terdapat hubungan di antara personaliti grit terhadap kesejahteraan subjektif. Namun begitu kajian ini hubungan korelasi yang sederhana. Aspek personaliti grit sememangnya mampu membentuk sikap pelajar yang mempunyai kemampuan untuk bertahan pada minat serta mempunyai ketekunan usaha. Kesan daripada sikap ketahanan minat dan ketekunan berusaha, pelajar akan memperoleh kesejahteraan subjektif yang lebih baik kerana berupaya meneruskan proses pembelajaran seperti mengikuti kelas atas talian secara konsisten, melibatkan diri dalam perbincangan bersama pensyarah dan rakan, serta mampu membentuk ketahanan diri dalam mengharungi cabaran pembelajaran di sepanjang musim pandemik. Apabila pelajar berjaya untuk mengikuti pembelajaran seperti yang diharapkan, pelajar akan mengalami kesejahteraan subjektif melalui peningkatan kepuasan dalam pembelajaran, kesyukuran, malah meningkatkan hubungan di antara diri dengan institusi pendidikan (Zhang \& Renshaw, 2020). Penjelasan ini turut disokong oleh Moen dan Olsen (2020) serta Septania (2020) yang telah menjalankan kajian berkenaan komponen Grit iaitu ketekunan usaha dan ketekalan minat menjadi penyumbang kepada kesejahteraan subjektif. Selain itu, hubungan grit dan kesejahteraan subjektif turut dijelaskan oleh Mazhar Khan dan Khan (2017) iaitu jika individu mempunyai ketekalan serta kegigihan untuk mengejar matlamat hidupnya, mereka akan berasa puas terhadap kehidupannya sertakan lebih bahagia apabila impiannya tercapai. Oleh itu, individu yang mempunyai grit yang tinggi, mereka mempunyai keinginan untuk mencapai sesuatu dan merasa bahagia apabila berjaya memperoleh apa yang diinginkannya.

Secara keseluruhan, dapatan kajian ini memberikan impak dan gambaran bahawa aspek personaliti grit dan kesejahteraan subjektif pelajar berada pada tahap yang baik namun masih boleh dipertingkatkan. Aspek ini penting kerana ia kemampuan pelajar menghadapi pembelajaran dalam keadaan yang mencabar mampu menjamin kesejahteraan mental dan keberkesanan pembelajaran. Selain itu juga, aspek personaliti grit mampu di jadikan sebagai peramal kepada kesejahteraan subjektif pelajar. Dapatan kajian ini juga selari dengan Teori Kesejahteraan Subjektif oleh Diener (1984), faktor sikap seperti personaliti dan ciri keperibadian mempengaruhi pembentukan perspektif serta kemahiran kognitif dalam penginterpretasian serta menilai pengalaman hidupnya. Pelajar yang mempunyai personaliti grit mempunyai sikap berusaha dan tabah dalam mengharungi cabaran yang dihadapi dalam pengalaman pembelajarannya. Sikap ini juga membolehkan pelajar menilai pengalamannya itu sesuatu pengalaman yang baik dan akhirnya mempamerkan emosi yang positif dan kepuasan dalam pembelajarannya. Dapatan ini juga menambahkan lagi maklumat dan pengetahuan berkenaan topik personaliti grit yang masih kurang dikaji secara menyeluruh.

\section{Kesimpulan}

Secara kesimpulan, kajian ini telah membuktikan bahawa pemboleh ubah personaliti grit dan kesejahteraan subjektif pelajar mempunyai hubungan yang signifikan dalam kalangan pelajar universiti di UKM. Dapatan ini menyimpulkan serta mencadangkan agar pelajar meningkatkan ketekunan dalam usaha serta ketekalan dalam mengekalkan minat untuk membentuk diri yang mempunyai persepsi yang bagus terhadap pengalaman pembelajaran walaupun dilanda cabaran dan tekanan seperti wabak pandemik Covid-19 yang mengubah suasana pembelajaran. Pelajar yang membina persepsi yang baik mampu membentuk respons tingkah laku seperti kesyukuran, keberkesanan akademik, hubungan harmoni di antara kenalan dan kepuasan terhadap pengalaman pembelajaran.

Walau bagaimanapun, terdapat beberapa penambahbaikan yang boleh dilakukan oleh pengkaji seterusnya. Dari sudut kaedah persampelan, kajian ini telah menggunakan persampelan rawak 
berkelompok. Menurut Rozmi (2013) teknik ini mempunyai kelemahan dari segi ralat persampelan yang lebih besar berbanding teknik persampelan kebarangkalian yang lain. Oleh itu, kajian seterusnya dicadangkan untuk menggunakan teknik persampelan rawak mudah. Selain itu juga, populasi kajian masih boleh dibesarkan bagi membolehkan dapatan kajian digeneralisasikan terhadap populasi pelajar peringkat pengajian tinggi di seluruh Malaysia. Seterusnya, dengan mengenal pasti tahap kesejahteraan subjektif pelajar semasa mengikuti pembelajaran sepanjang musim pandemik ini, pihak yang berkenaan khususnya institusi pengajian tinggi, para pensyarah dan pihak kementerian perlu berganding bahu untuk memastikan keadaan pelajar adalah sejahtera. Para pensyarah boleh mendapatkan maklum balas daripada pelajar secara berkala untuk mendengar luahan dan cadangan agar pelajar bersemangat dan tabah untuk mengharungi cabaran dalam menuntut ilmu. Di samping itu juga, aktiviti ini turut meningkatkan hubungan yang positif di antara pensyarah dan pelajar.

\section{Rujukan}

Ariati, J. (2010). Subjective well-being (kesejahteraan subjektif) dan kepuasan kerja pada staf pengajar (dosen) di lingkungan fakultas psikologi universitas diponegoro. Jurnal Psikologi Undip, 8(2), $117-123$.

Arya, B. \& Lal, D. S. (2018). Grit and sense of coherence as predictors of well-being. Indian Journal of Positive Psychology, 9(01), 169-172.

Azlin, F. \& Mohamad, M. (2019). The effect of grit on work performance and psychological wellbeing: analytical study of grit literature. IIUM Journal of Human Sciences, 1, 10-16.

Bibi Yusuf, B. N. (2020). Are we prepared enough? A case study of challenges in online learning in a private higher learning institution during the Covid-19 outbreaks. Advances in Social Sciences Research Journal, 7(5), 205-212.

Calo, Marlena, Casey Peiris, Lucy Chipchase, Felicity Blackstock, and Belinda Judd. 2019. Grit, resilience and mindset in health students. Clinical Teacher, 16(4), 317-22. doi: 10.1111/tct.13056.

Cohen, L., Manion, L., \& Morrison, K. (2013). Validity and reliability. In Research methods in education (pp. 203-240). Routledge.

Crawford, J. \& Irving, C. (2009). Information literacy in the workplace: A qualitative exploratory study Journal of Librarianship and Information Science, 41(1), 29-38.

Datu, J. A. D. 2017. Sense of relatedness is linked to higher grit in a collectivist setting. Personality and Individual Differences, 105, 135-138.

Daud, S., Wan Hanafi, W. N., Wan Abdullah, W. M. T., Ahmad, N. N. \& Toolib, S. N. (2020). Applying health belief model in assessing malaysian graduate' $\mathrm{s}$ emotional wellness post covid 19 outbreak: A conceptual paper. Global Business and Management Research: An International Journal, 12(4), 580-588.

Diener, E., Suh, M., Lucas, E. \& Smith, H. (1999). Subjective weil-being: Three decades of progress. Psychological Bulletin, 125(2), 276-302.

Diener, Ed. (1984). Subjective well-being. Psychological Bulletin, 95(3), 542-575.

Diener, Ed, Oishi, S. \& Lucas, R. E. (2003). Personality, culture, and subjective well-being: Emotional and cognitive evaluations of life. Annual Review of Psychology, 54, 403-425.

Disabato, D. J., Goodman, F. R. \& Kashdan, T. B. (2019). Is grit relevant to well-being and strengths? Evidence across the globe for separating perseverance of effort and consistency of interests. Journal of Personality, 87(2), 194-211.

Duckworth, A. L., Peterson, C., Matthews, M. D. \& Kelly, D. R. (2007). Grit: Perseverance and passion for long-term goals. Journal of Personality and Social Psychology, 92(6), 1087-1101.

Hayden, Dorian. (2018). Coping with being cut from the team: examining grit, resilience and optimism in response to failure in college athletes.

Jeong, G. C. \& Jin, Y. H. (2020). Mediating effect of grit in the relationship between basic psychological needs and subjective well-being: Comparative study of korean and chinese adolescents. The Journal of the Korea Contents Association, 20(8), 397-407.

Jiang, W., Jiang, J., Du, X., Gu, D., Sun, Y. \& Zhang, Y. (2020). Striving and happiness: Betweenand within-person-level associations among grit, needs satisfaction and subjective well-being. Journal of Positive Psychology, 15(4), 543-555. 
Jin, B., \& Kim, J. (2017). Grit, basic needs satisfaction, and subjective well-being. Journal of Individual Differences, 38(1), 29.

Kahneman, D. \& Krueger, A. B. (2006). Developments in the measurement of subjective well-being. Journal of Economic Perspectives, 20(1), 3-24.

Kerlinger, F.N. (1975). Review of Research in Education. (Engelhart, M. D., Ed.). Peacock Publishers.

Khan, B. M, \& Khan, A. M. (2017). Grit, happiness and life satisfaction among profesionals: A correlational study. Journal of Psychology and Cognition, 2(2), 123-132.

Lam, K. K. L. \& Zhou, M. (2019). Examining the relationship between grit and academic achievement within K-12 and higher education: A systematic review. Psychology in the Schools, 56(10), $1654-1686$.

Lee, Chang Seek. (2018). Employment stress and wellbeing of university students in Korea: The mediating effects of growth mindset, grit, and hope. Medico-Legal Update, 18(1), 254-59. doi: 10.5958/0974-1283.2018.00054.3.

Li, Jingguang, Li Lin, Yajun Zhao, Jing Chen, and Song Wang. (2018). Grittier Chinese adolescents are happier: The mediating role of mindfulness. Personality and Individual Differences, 131(April):232-37. doi: 10.1016/j.paid.2018.05.007

Moen, F. \& Olsen, M. (2020). Grit: A unique protective factor of coaches well-being and burnout? New Ideas in Psychology, 59, 100794.

Muhammad Salehan, Alhafiz Mat \& Rohana Hamzah. (2020). Model kebahagiaan hidup pelajar universiti berdasarkan faktor kesihatan mental, kecerdasan spiritual dan demografi Malaysian Journal of Social Sciences and Humanities (MJSSH), 5(11), 17-32.

Nik Mohd Rahimi. (2004). Kemahiran mendengar bahasa Arab: Satu Kajian di sekolah menengah kerajaan negeri. Unpublished Ph. D, Universiti Kebangsaan Malaysia, Bangi.

Nora Izaach, R. (2017). Gambaran derajat grit pada mahasiswa akademi keperawatan "x" di kabupaten Kepulauan Aru, Bandung. Humanitas, 1, 61-70.

Nunnally. J.C. \& Bernstein. I.H. (1994). Pychhometric Theory (3rd ed.). New York: McGraw-Hill.

Nunnally, J.C. (1978). An Overview of Psychological Measurement. (Wolman, B. B., Ed.). New York.: Plenum Press.

Pallant, J. (2013). SPSS survival manual: A step by step guide to data analysis using IBM SPSS. Routledge.

Perry RH, Charlotte B, Isabella M, Bob C. (2004). SPSS Explained. Routledge: Taylor \& Francis Group.

Renshaw, T. L. \& Bolognino, S. J. (2016). The college student subjective wellbeing questionnaire: A brief, multidimensional measure of undergraduate's covitality. Journal of Happiness Studies, $17(2), 463-484$.

Rozmi Ismail. (2013). Metodologi penyelidikan: Teori dan praktis. Penerbit Universiti Kebangsaan Malaysia.

Septania, S. (2020). Surviving the Covid-19 pandemic : Analysis of the Grit factor in students. Jurnal Pengukuran Psikologi dan Pendidikan Indonesia, 9(2), 68-74.

Zacher, H. \& Rudolph, C. W. (2021). Individual differences and changes in subjective wellbeing during the early stages of the COVID-19 pandemic. American Psychologist, 76(1), 50-62.

Zhang, Don C., and Tyler L. Renshaw. 2020. Personality and college student subjective wellbeing: A domain-specific approach. Journal of Happiness Studies, 21(3), 997-1014. doi: 10.1007/s10902019-00116-8. 